\title{
Italian risk-sharing agreements on drugs: are they worthwhile?
}

\author{
Livio Garattini $\cdot$ Alessandro Curto • \\ Katelijne van de Vooren
}

Published online: 12 April 2014

(c) Springer-Verlag Berlin Heidelberg 2014

Both payers and manufacturers have shown increasing interest in risk-sharing schemes, since they are expected to serve as a mechanism for reducing uncertainty through greater investment in collecting clinical evidence once a new drug is already being used in a health care system. The underlying philosophy is to pay only for patients responding to therapy, a very challenging issue in a clinical perspective, while appealing from a political viewpoint. Recently, an international group of experts proposed to call them "Performance-Based Risk-Sharing Arrangements", a highly complex definition indeed [1]. These contracts exist in many varieties, generally as a reaction to the increasing costs of expensive new drugs, while more data are still needed to thoroughly assess their effectiveness. In principle, they could provide additional options to payers and manufacturers, to boost overall efficiency [2]. The ambitious goal is to help reduce the likelihood of payers adopting technologies that turn out not to be cost effective, while at the same time helping manufacturers earn profitable prices to invest in future innovative technologies.

Italy is one of the countries that started early with these agreements: AIFA, the Italian drug agency, agreed on its first contract in July 2006 [3]. The complex management of these schemes, now called managed entry agreements (MEAs) by AIFA, and similar to the patient access schemes in the UK, is entirely based on web-registries.

Hospital consultants are required to complete an on-line prescription form, with the patient's identification data, therapeutic indication and dosages. The system validates

L. Garattini $(\triangle) \cdot$ A. Curto $\cdot$ K. van de Vooren CESAV, Centre for Health Economics, IRCCS Institute for Pharmacological Research 'Mario Negri', Via Camozzi, 3 c/o Villa Camozzi, Ranica, 24020 Bergamo, Italy

e-mail: livio.garattini@marionegri.it each prescription and automatically requests the hospital pharmacy to release the drug. Every single prescription is tracked to monitor appropriate use of innovative and expensive specialist drugs. AIFA has published on its website a very accurate estimate of the time required by a hospital consultant and a pharmacist to complete the most important forms, even splitting these estimates for expert and non-expert professionals [4]. However, the negligible average times estimated to complete some forms-e.g. $30 \mathrm{~s}$ for an experienced consultant for forms focused on diagnosis, $10 \mathrm{~s}$ for a pharmacist for those needed for dispensing-hardly seem realistic, taking account of the varieties of drugs and indications.

Twenty-nine MEAs were in force as of October 2012 [5], for 25 drugs (Table 1). Three different types of agreement can be stipulated with pharmaceutical companies: (1) costsharing (CS, $n=11)$, (2) risk-sharing (RS, $n=2$ ) and (3) payment-by-results ( $\mathrm{PbR}, n=16)$. CS implies just a price discount, usually limited to the first 2-3 months or cycles of therapy. These discounts are normally monetary and manufacturers are expected to do a pay-back. The other two contracts are based on the rates of "non-responders". The manufacturer is expected to pay back part of (RS) or the full price $(\mathrm{PbR})$ for each non-responding patient. If a patient meets "non-responder" criteria, the hospital pharmacist should apply to the manufacturer for pay-back not later than the end of the year; the manufacturer can accept or reject the proposal (requiring arbitration) [5].

\section{Revenues}

In September 2013, AIFA published the revenues of MEAs for the first time [5]. The total theoretical pay-back was $€ 46.3$ million. However, the report pointed out that one- 
third of this could not be clawed back because of disputes with pharmaceutical companies $(22 \%)$ or late requests by hospitals ( $11 \%$ ); thus, only $€ 31.3$ million were eventually collected, around $5 \%$ of the total expenditure for the drugs involved (limited to the indications under MEA). Although complete information by drug and by region were not available, more than $80 \%$ of the theoretical pay-back in 2012 was reported to refer to only 9 active substances, the remaining 17 contributing for less than 1 million euros each.

As expected, CS agreements seem more efficient than $\mathrm{RS}$ and $\mathrm{PbR}$ in producing revenues [5]; a scheme based on a simple discount should be much easier to manage than one referring to clinical outcomes, which imply pre-set evaluation timing, often hard to establish [6].

\section{Costs}

To assess the efficiency of MEAs, their management costs need to be taken into account. MEAs have been managed up to June 2012 by a non-profit consortium made up of 68 Italian universities and 3 institutions [7]. AIFA asked companies to pay this provider a fee on a yearly basis for each product under a MEA, including implementation and maintenance for the first year, then only the latter from the following year. According to an informal inquiry we made with three companies on four products, the fee varied from $€ 30,000$ to $€ 60,000$ for the first year, then more than halved for the subsequent years. Presumably, these differences were due to the complexity and potential volume of the forms, although no information was made available on the criteria for setting these fees.

Table 1 List of risk-sharing contracts in Italy (2012) [5]

\begin{tabular}{|c|c|c|c|}
\hline & INN & $\begin{array}{l}\text { Type of } \\
\text { MEA }\end{array}$ & Therapeutic indications under monitoring \\
\hline 1 & Azacitidine & CS & Myelodysplastic syndromes, Chronic myelomonocytic leukaemia, Acute myeloid leukaemia \\
\hline 2 & Bevacizumab & $\mathrm{CS}$ & Metastatic colorectal cancer, Head and neck cancer, Breast cancer, Lung cancer, Renal cancer \\
\hline 3 & Bortezomib & CS & Multiple myeloma, Refractory/relapsed multiple myeloma, Amyloidosis \\
\hline 4 & Brentuximab & $\mathrm{PbR}$ & Anaplastic lymphoma, Hodgkin lymphoma \\
\hline 5 & Catumaxomab & CS & Malignant ascites \\
\hline \multirow[t]{2}{*}{6} & Cetuximab & $\mathrm{PbR}$ & Colorectal cancer \\
\hline & & $\mathrm{RS}$ & Head and neck cancer \\
\hline 7 & Eribulin & $\mathrm{PbR}$ & Metastatic breast cancer \\
\hline 8 & Erlotinib & $\mathrm{CS}$ & Lung cancer (first line) \\
\hline 9 & Everolimus & $\mathrm{PbR}$ & Renal cancer \\
\hline 10 & Gefitinib & $\mathrm{PbR}$ & Non-small-cell lung cancer \\
\hline 11 & Lapatinib & $\mathrm{PbR}$ & Advanced or metastatic breast cancer \\
\hline 12 & Lenalidomide & CS & Multiple myeloma, Diffuse large B cell lymphoma, Amyloidosis, Mantle-cell lymphoma \\
\hline \multirow[t]{2}{*}{13} & Nilotinib & CS & Newly diagnosed myelogenous leukaemia in the chronic phase \\
\hline & & $\mathrm{PbR}$ & $\begin{array}{l}\text { 'Chronic' and 'accelerated' phases of chronic myelogenous leukaemia resistant or intolerant to other } \\
\text { treatments including imatinib }\end{array}$ \\
\hline 14 & Ofatumumab & $\mathrm{CS}$ & Chronic lymphocytic leukaemia \\
\hline 15 & Panitumumab & $\mathrm{RS}$ & Renal cancer, Metastatic colorectal cancer \\
\hline 16 & Pazopanib & $\mathrm{PbR}$ & Renal cancer \\
\hline 17 & Pegaptanib & $\mathrm{PbR}$ & Neovascular (wet) age-related macular degeneration \\
\hline 18 & Plerixaflor & $\mathrm{PbR}$ & $\begin{array}{l}\text { Collection of haematopoietic stem cells and subsequent autologous transplantation in patients with lymphoma } \\
\text { and multiple myeloma }\end{array}$ \\
\hline 19 & Ranibizumab & $\mathrm{PbR}$ & $\begin{array}{l}\text { Neovascular (wet) age-related macular degeneration, Macular oedema caused by diabetes, Macular oedema } \\
\text { casued by occlusion of the veins behind the retina }\end{array}$ \\
\hline \multirow[t]{2}{*}{20} & Sorafenib & $\mathrm{PbR}$ & Renal cancer \\
\hline & & $\mathrm{CS}$ & Liver cancer \\
\hline 21 & Sunitinib & CS & Renal cancer \\
\hline \multirow[t]{2}{*}{22} & Temsirolimus & $\mathrm{PbR}$ & Renal cancer \\
\hline & & $\mathrm{CS}$ & Mantle-cell lymphoma \\
\hline 23 & Trabectedin & $\mathrm{PbR}$ & Ovarian cancer, Soft-tissue sarcoma \\
\hline 24 & Trastuzumab & $\mathrm{PbR}$ & Metastatic gastric (stomach) cancer \\
\hline 25 & Vinfluvin & $\mathrm{PbR}$ & Advanced or metastatic 'transitional-cell carcinoma of the urothelial tract' \\
\hline
\end{tabular}

$C S$ cost sharing, INN International non-proprietary name, $M E A$ managed entry agreement, $P b R$ payment by result, $R S$ risk sharing 
In May 2012, AIFA opted for a more transparent system, awarding a 3 -year tender for $€ 8.7$ million to a private international leading consulting company. However, in practice, this led to an interruption in service at the end of 2012, because of incompatibility between the old and the new information technology (IT) systems, which seems to have continued in 2013 and should undermine most of the pay-back for this year. Moreover, AIFA will have to "pay the bill" for this new contract, unless it asks companies to share the costs.

The total direct cost for managing these registries should be around $€ 1$ million according to what AIFA reports on its website, although this might be an underestimate since other costs (e.g. IT maintenance) must also be considered.

Last, but not least, a cost item to be included should be the hospital consultants' and pharmacists' time for completing the forms. It is very likely to be considerable, but it is hard to estimate since at present no information is retrievable on the number of forms.

\section{Clinical outcomes}

To our knowledge, no published report has included clinical data on drugs subjected to RS/PbR agreements and, more in general, under AIFA registries, except for a summary report very early in 2007 [8]. Going through the forms referring to the patients' clinical status (all available on the AIFA website) [9], it is clear that they closely reflect the approval indication, hardly asking for any additional information useful for an extended clinical assessment. So the information collected is unlikely to contribute to the existing evidence on the drugs under these agreements, beyond self-certified validation of appropriate prescription by the prescriber.

To conclude, the national report claims that "AIFA is the only regulatory agency in the world to have designed a tool like this (MEA) for the very early phases of market access and price negotiation with pharmaceutical companies for a drug" [5]. We wonder whether the AIFA effort to become a "registry factory" is worthwhile after having analysed the existing information.

\section{References}

1. Garrison, L.P., Towse, A., Briggs, A., et al.: ISPOR task force reports: performance-based risk-sharing arrangements: good practices for design, implementation, and evaluation: report of the ispor good practices for performance-based risk-sharing arrangements task force. Value Health 16, 703-719 (2013)

2. Towse, A., Garrison, L.P.: Can't get no satisfaction? Will pay for performance help? Pharmacoeconomics 28, 93-102 (2010)

3. Agenzia Italiana del Farmaco. Registro Farmaci Oncologici sottoposti a Monitoraggio Rapporto Nazionale 2007. http://antineoplas tici.agenziafarmaco.it/rapporto_RFOM_2007.htm. Accessed 19 Mar 2014

4. Agenzia Italiana del Farmaco. Tempi di compilazione. http:// antineoplastici.agenziafarmaco.it/info_generali.htm. Accessed 20 Dec 2013

5. Agenzia Italiana del Farmaco. L'uso dei farmaci in Italia. Rapporto nazionale anno 2012. Osservatorio Nazionale sull'impiego dei Medicinali, OsMed. Roma, (2013). http://www.agenzia farmaco.gov.it/it/content/rapporti-osmed-luso-dei-farmaci-italia. Accessed 19 Mar 2014

6. Garattini, L., Casadei, G.: Risk sharing agreements: what lessons from Italy? Int. J. Technol. Assess. Health Care 27, 169-172 (2011)

7. Cineca. http://www.cineca.it/en. Accessed 19 Mar 2014

8. Agenzia Italiana del Farmaco. Registro Farmaci Oncologici sottoposti a Monitoraggio. Rapporto Nazionale 2007. http:// www.agenziafarmaco.gov.it/sites/default/files/rapporto_rfom_ 2008_0.pdf

9. Agenzia Italiana del Farmaco. Lista aggiornata dei nuovi Registri. http://www.agenziafarmaco.gov.it/it/content/lista-aggiornata-deinuovi-registri. Accessed 19 Mar 2014 